\title{
THE FABRICATION OF NATURAL ZEOLITE VIA CO-PRECIPITATION METHOD AS Cu, Pb AND Zn METAL ABSORBENT
}

\author{
M.Sirait ${ }^{1 *}$, K.Sari Dewi Saragih¹, Nurfajriani², S.Gea \\ 'Department of Physics, Faculty of Mathematics and Natural Sciences, \\ Universitas Negeri Medan, Jl. Willem Iskandar Pasar V, Medan 20221, \\ INDONESIA \\ 2Department of Chemistry, Faculty of Mathematics and Natural Sciences, \\ Universitas Negeri Medan, Jl. Willem Iskandar Pasar V, Medan 20221, \\ INDONESIA \\ ${ }^{3}$ Department of Chemistry, Faculty of Mathematics and Natural Sciences, \\ University of North Sumatra, Jl. Bioteknologi No. 1, Medan 20155, INDONESIA \\ *e-mail:maksir@unimed.ac.id
}

Heavy metal waste is very dangerous, which can change the condition of water into a solid substance that can be suspended in water and can reduce the cleanliness level of water consumed by living things. To date, heavy metals can be managed through several processes, namely physics, biology or chemistry. One of the ways to overcome heavy metal pollution is to use natural zeolite applying a co-precipitation method, as it is known that zeolite is a powerful natural material to be used for certain purposes. In order to justify the research results, several analyses have been performed, such as X-Ray Diffraction (XRD), Scanning Electron Microscopy (SEM), Surface Area Analyser (SAA), and Atomic Adsorption Spectrophotometric (AAS). From the XRD results, it has been found out that the size of each zeolite with variations in size of 150 mesh, 200 mesh, and 250 mesh is $29.274 \mathrm{~nm}, 38.665 \mathrm{~nm}$ and $43.863 \mathrm{~nm}$, respectively. Moreover, the SEM-EDX has shown that the zeolite under consideration is a type of Na-Zeolite and that the co-precipitation method successfully removes impurity elements, namely, $\mathrm{Fe}$, Ti, and $\mathrm{Cl}$. The results of SAA testing have indicated that the total surface area for each variation of zeolite sizes is $63.23 \mathrm{~m}^{2} / \mathrm{g}, 45.14 \mathrm{~m}^{2} / \mathrm{g}$ and $59.76 \mathrm{~m}^{2} / \mathrm{g}$. The results of the AAS test analysis have demonstrated that the optimal absorption of metal content is observed in a size of 150 mesh zeolite with adsorption power of $99.6 \%$ for $\mathrm{Pb}$ metal, $98 \%$ for $\mathrm{Cu}$ metal, and $96 \%$ Zn metal.

Keywords: Co-precipitation method, metal adsorbent, natural zeolite 
Aquatic environment pollution caused by heavy metals is transforming into a serious problem in public health and significant environmental issues. Mining activities, household waste liquids, industrial waste and agricultural waste are reported to be the main contributors to pollute the aquatic environment [1]-[4]. Natural zeolite is formed due to the existence of complex chemical and physical processes from rocks, which experience various kinds of changes in nature. Geochemists and mineralogists estimate that zeolites are frozen volcanic products, which then turn into volcanic rocks, sedimentary rocks and metamorphic rocks. Then, they subsequently undergo weathering due to the effects of heat and cold. Zeolite structures can be divided into three components, namely, alumino silicate frame, empty space interconnected containing metal cations and water molecules in the occluded phase [5].

One way to overcome heavy metal pollution is by applying natural zeolite. Zeolite is commonly used as a catalyst in various acid catalyst reactions [6]-[9]. The adsorption method is an alternative method to minimize the presence of pollutants in the environment [10]-[14]. Moreover, by synthesizing the zeolite via co-precipitation method and combining it with the acid, such as hydrochloric acid $(\mathrm{HCl})$, it can give a significant effect, since hydrochloric acid is known as an acid capable of dissolving inorganic compounds [15], [16].

The co-precipitation method is a bottom up synthesis method that is used to obtain small nanometer sized particles [17]. This method has the principle of removing the continuous bond that is owned by a metal compound in the form of liquid without considering the specific mechanism that occurs. By using the co-precipitation method, a solid material is obtained from its aqueous precipitate [18].

Finally, it is necessary to investigate and research an active natural zeolite to be more optimal and efficient in its performance as an adsorbent. This adsorption property will be focused on removing metals as pollutants such as copper $(\mathrm{Cu})$ and lead $(\mathrm{Pb})$. Adsorption has been chosen as the best method for it is efficient and reliable.

\section{EXPERIMENTAL}

Concentrated hydrochloric acid, copper metal, lead metal, zync metal and distilled water were purchased from merck and used for the research. Moreover, ball mill and several characterisation and analysis equip-

\subsection{The Synthesis of Zeolite}

Natural zeolite was dried in the furnace with various temperature levels. The first heating was reaching at $200{ }^{\circ} \mathrm{C}$ for $30 \mathrm{~min}$ utes, then it was increased to $400{ }^{\circ} \mathrm{C}$ for 30 ment, namely X-ray Diffraction (XRD), Atomic Absorption Spectroscopy (AAS), Surface Area Analyser (SAA) and Scanning Electron Microscopy (SEM) were utilised.

minutes. Finally, the heating temperature was increased to $600{ }^{\circ} \mathrm{C}$ for 1 hour, which aimed at removing the water content in the zeolite to ease the grinding process. 
Zeolite was crushed to break the zeolite stones and then sieved with 200 mesh sieves. Furthermore, zeolite powder was treated with ball mill type planetary ball mill for 2 hours with $400 \mathrm{rpm}$ rotation and sieved with 200 mesh sieve to produce a smoother powder zeolite. Finally, it was characterised by using SEM-EDX and XRD method.

As much as $20 \mathrm{~g}$ of zeolite powder from the previous treatment was put into a beaker glass and then dissolved in $100 \mathrm{ml}$ of $12 \mathrm{M}$ $\mathrm{HCl}$, then heated in a magnetic stirrer at the temperature range of $70{ }^{\circ} \mathrm{C}-90{ }^{\circ} \mathrm{C}$ for 120 minutes. Then, it was stirred at $350 \mathrm{rpm}$,

\subsection{The Metal Adsorbent Test}

As much as $0.2 \mathrm{~g}$ of $\mathrm{Pb}, \mathrm{Cu}$ and $\mathrm{Zn}$ were weighed and then poured into a beaker glass and added with $1200 \mathrm{~mL}$ of distilled water. Then, it was stirred at room temperature at a rotation speed of $300 \mathrm{rpm}$ until mixed evenly. After that, as much as $1 \mathrm{~g}$ of zeolite combined with $\mathrm{HCl}$ with various particle size of 150, 200 and 250 mesh was put in three beaker glasses. Then, as much as 300 $\mathrm{mL}$ of the solution containing metals was and also heated at the temperature range of $70{ }^{\circ} \mathrm{C}-90{ }^{\circ} \mathrm{C}$ for 120 minutes. The mixture was then neutralized with distilled water.

The mixture was dried in the oven for 5 hours at the temperature of $100{ }^{\circ} \mathrm{C}$. The dried mixture was crushed using a mortar to smoothen and turn it into powder. The zeolite powder was calcined in a furnace at the temperature of $600{ }^{\circ} \mathrm{C}$. After calcination process, zeolite powder was milled using a ball mill at a speed of $100 \mathrm{rpm}$ for $30 \mathrm{~min}$ utes, and sieved to produce zeolite. Zeolites combined with $\mathrm{HCl}$ solvents were tested by SEM-EDX, XRD, and SAA method.

poured into each of zeolite with various particle size and into one beaker glass that did not contain zeolite (blank).

The solution mixed with zeolite was stirred at a room temperature at a rotation speed of $300 \mathrm{rpm}$ for 1 hour. The mixtures were filtered with Whatman paper to separate the solution and adsorbent materials. Finally, it was characterised by using the AAS method.

\section{RESULTS AND DISCUSSION}

Zeolites in the form of chunks were first put in the furnace at the temperature of $600{ }^{\circ} \mathrm{C}$ for 4 hours. The zeolite chunks were crushed with mortal and then sieved with 150 mesh, 200 mesh, and 250 mesh sieves. The sieve results were milled with the planetary ball mill at a rotation speed

\subsection{XRD (X-Ray Diffraction) Analysis}

X-ray diffraction method is an analytical method based on the interaction between matter with X-ray electromagnetic radiation (having $\lambda=0.5-2.5 \AA \AA$ and energy $\pm 107 \mathrm{eV}$ ), which is the measurement of diffracted X-ray radiation by the field crystal. of $300 \mathrm{rpm}$ for 2 hours to produce zeolite powder.

Then, the size variations were carried out with the aim of discovering which zeolite would have optimum adsorption of heavy metal ions and have the largest surface area.

Moreover, in the present research, the XRD characterisation used the Shimadzu type XRD tool with Ka wavelength of 1.541862 $\AA$ and speed (scan speed) of 2 degree/min. The XRD characterisation results are displayed in Fig. 1. 


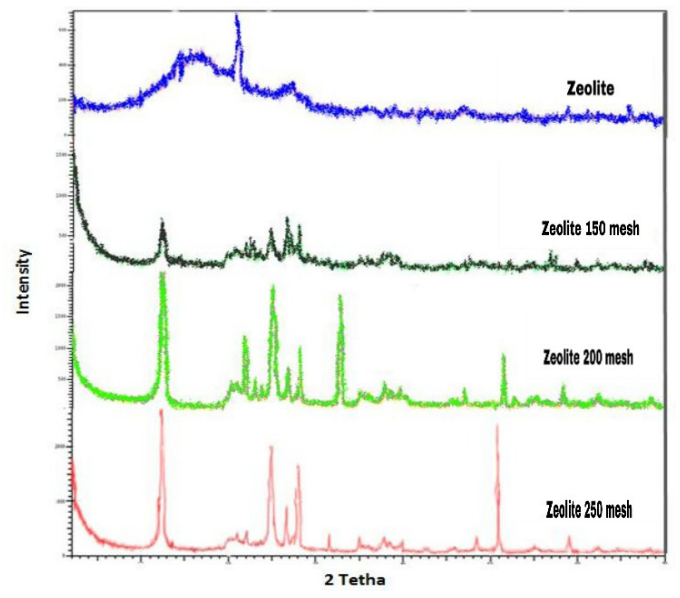

Fig. 1. The XRD result of:

Zeolite after milling process, zeolite 150 mesh, zeolite 200 mesh and zeolite 250 mesh.
Based on the XRD results, it can be seen that the size of each zeolite with variations in the size of 150 mesh, 200 mesh, and 250 mesh is $29.274 \mathrm{~nm}, 38.665 \mathrm{~nm}$ and 43.863 $\mathrm{nm}$, respectively. Furthermore, the crystal structure of zeolite after milling process, zeolite 150 mesh, zeolite 200 mesh, zeolite 250 mesh are trigonal, tetragonal and cubical, respectively.

Particle size can affect material properties; a smaller size affects a larger surface area causing greater or more responsive reaction power [19], [20]. Furthermore, changes in material properties (chemical properties and thermal properties) lead to changes in the structure of the material; this structure also illustrates the strength of the material [21].

\subsection{Scanning Electron Microscope (SEM) Analysis}

The characterisation using Scanning Electron Microscopy (SEM) is expected to determine the morphological structure of a material. Through SEM analysis, the pore particle size can be seen in the sample with a certain magnification; besides, the composition of the material can be determined through an EDX tool that is integrated with the tool.

The smaller the size of the adsorbent pores, the higher the surface area so that the number of molecules adsorbed will increase. From the results of the analysis of the composition of the SEM-EDX compound, it is known that zeolite under consideration was $\mathrm{Na}$-Zeolite type. Zeolite before being co-precipitated had a rough surface and agglomerated, whereas zeolite that was co-precipitated had a smooth surface and less agglomeration. The zeolite synthesis of the co-precipitation method succeeded in removing impurities, namely, Fe.

Table 1. The Element Composition Obtained from the EDX Analysis

\begin{tabular}{|l|c|c|c|c|}
\hline \multirow{2}{*}{ Chemical Elements } & \multicolumn{4}{|c|}{ Mass [\%] } \\
\cline { 2 - 5 } & Zeolite & Zeolite 150 mesh & Zeolite 200 mesh & Zeolite 250 \\
\hline $\mathrm{Si}$ & 14.40 & 15.10 & 18.71 & 30.65 \\
\hline $\mathrm{Al}$ & 32.86 & 15.09 & 17.49 & 16.33 \\
\hline $\mathrm{Fe}$ & 10.04 & 1.20 & 0.74 & - \\
\hline $\mathrm{Ti}$ & - & 0.13 & 0.34 & 4.64 \\
\hline $\mathrm{C}$ & 4.80 & 8.73 & 7.56 & - \\
\hline $\mathrm{Cl}$ & 3.31 & 0.61 & 0.84 & 48.38 \\
\hline $\mathrm{O}$ & 34.58 & 58.91 & 52.85 & - \\
\hline
\end{tabular}




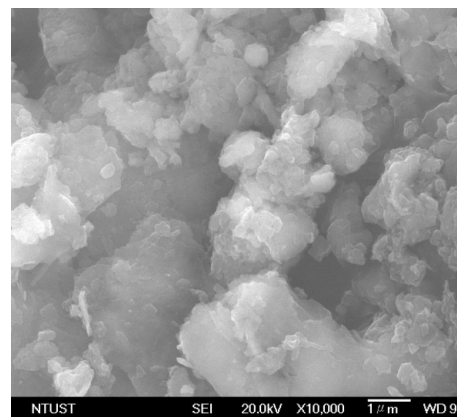

(a)

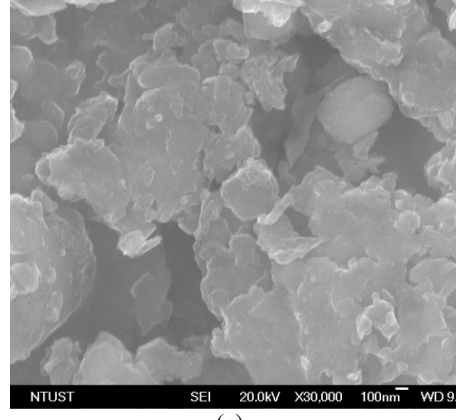

(c)

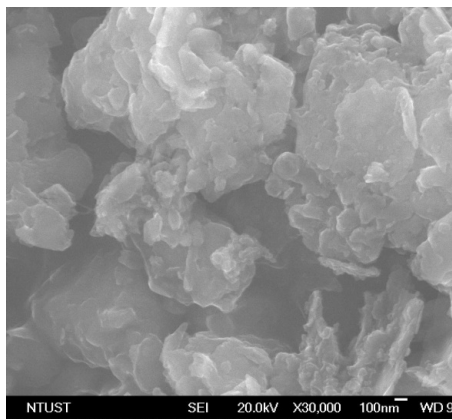

(b)

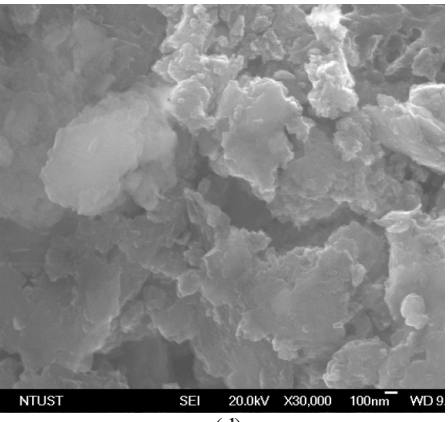

(d)

Fig. 2. The SEM result of: (a) zeolite after milling process, (b) zeolite 150 mesh, (c) zeolite 200 mesh and (d) zeolite 250 mesh.

\subsection{Analysis of Surface Area Analyser (SAA)}

Surface Area Analyser has several methods with one of them in the form of Gas Surface Analyser, which uses gas to analyse the surface area of a porous material with desorption adsorption techniques applying adsorbate inert gases such as nitro- gen or helium and adsorbent in the form of porous material. Zeolite is said to be physically adsorbed, which only occurs in the interaction between the molecule adsorbent and the adsorbate.

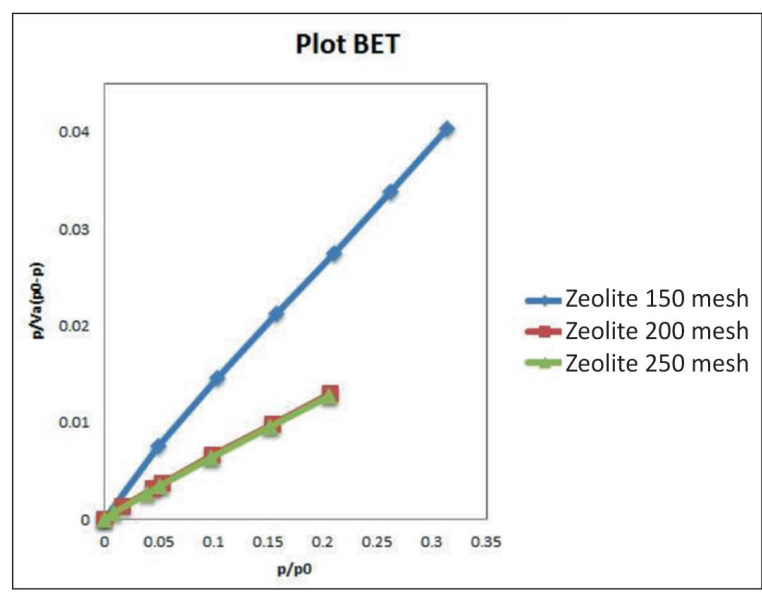

Fig. 3. The BET plot result of zeolite 150 mesh, zeolite 200 mesh and zeolite 250 mesh. 
The SAA test results revealed that the total surface area of the zeolite variation of 150 mesh, 200 mesh, 250 mesh were 32.07 $\mathrm{m}^{2} / \mathrm{g}, 65.36 \mathrm{~m}^{2} / \mathrm{g}$ and $65.06 \mathrm{~m}^{2} / \mathrm{g}$, respectively, with specific surface area (BET) variations in each size $-323.95 \mathrm{~m}^{2} / \mathrm{g}$, $660.26 \mathrm{~m}^{2} / \mathrm{g}$ and $657.18 \mathrm{~m}^{2} / \mathrm{g}$. Furthermore, the calculation results of BET analysis on the surface area of each zeolite size are as follows (see Table 2).

Table 2. The Calculation Result of BET Analysis

\begin{tabular}{|l|l|l|l|}
\hline Sample & Zeolite 150 mesh & Zeolite 200 mesh & Zeolite 250 mesh \\
\hline Slope & $1.22 \times 10^{-1}$ & $5.99 \times 10^{-2}$ & $6.05 \times 10^{-2}$ \\
\hline Intercept & $2.04 \times 10^{-3}$ & $7.07 \times 10^{-4}$ & $4.00 \times 10^{-4}$ \\
\hline Surface Area & $3.52 \times 10^{1}$ & $7.18 \times 10^{1}$ & $7.15 \times 10^{1}$ \\
\hline $\mathrm{Wm}\left(\mathrm{m}^{2} / \mathrm{g}\right)$ & 8.09 & $1.65 \times 10^{1}$ & $1.64 \times 10^{1}$ \\
\hline $\mathrm{St}\left(\mathrm{m}^{2} / \mathrm{g}\right)$ & $3.21 \times 10^{1}$ & $6.54 \times 10^{1}$ & $6.51 \times 10^{1}$ \\
\hline $\mathrm{S}\left(\mathrm{m}^{2} / \mathrm{g}\right)$ & $3.24 \times 10^{2}$ & $6.60 \times 10^{2}$ & $6.57 \times 10^{2}$ \\
\hline Error $(\%)$ & 8.9761 & 8.9718 & 8.9714 \\
\hline
\end{tabular}

\subsection{Atomic Adsorption Spectrophotometric (AAS) Analysis}

The results of the AAS analysis showed that the optimum adsorption of metal content was using zeolite variations in size of 150 mesh with adsorption power of $99.6 \%$ for $\mathrm{Pb}$ metal, $98 \%$ for $\mathrm{Cu}$ metal, and $96 \%$ Zn metal. The zeolite 200 mesh adsorption power was $\mathrm{Pb} 96.97 \%$, Zn 99.694 \%, and $\mathrm{Cu} 97.51 \%$, while zeolite 250 mesh adsorption power was $\mathrm{Pb} 99.92$ \%, Zn 99.684 \%, and $\mathrm{Cu} 99.978 \%$.

At the time of exchange of heavy metal ions with zeolites, it will be confused with zeolite elements which have weak ionization, so that zeolites can absorb the metal ions. The second indicator that causes high absorption results is because the small particle size will increase the surface area, causing higher absorption properties.

Table 3. The Metal Content of Each Size Variation of Zeolite

\begin{tabular}{|l|l|l|l|}
\hline Sample & $\mathrm{Pb}(\mathrm{mg} / \mathrm{L})$ & $\mathrm{Zn}(\mathrm{mg} / \mathrm{L})$ & $\mathrm{Cu}(\mathrm{mg} / \mathrm{L})$ \\
\hline Without indicator & 591.6 & 0.5264 & 0.2709 \\
\hline Zeolite 150 mesh & 0.1051 & 0.1636 & $<0.006$ \\
\hline Zeolite 200 mesh & 6.49 & 0.1611 & 0.6734 \\
\hline Zeolite 250 mesh & $<0.005$ & 0.5880 & $<0.006$ \\
\hline
\end{tabular}

Based on the table above, it can be seen that there is a decrease in metal content when using nano zeolite. The optimal metal absorption uses $\mathrm{HCl}$ solvent where there is a decrease in metal content for all $\mathrm{Pb}, \mathrm{Zn}$ and $\mathrm{Cu}$ metals. It can be inferred that the co-precipitation method applied to natural zeolite and converted to several size variations is proven to be able to show a good performance for metal adsorbent. 


\section{CONCLUSION}

The fabrication of natural zeolite via the co-precipitation method has been successfully performed. Furthermore, this material shows an impressive capability as a metal adsorbent, particularly copper, lead and zinc.

\section{ACKNOWLEDGEMENTS}

The authors would like to thank the Rector of the Universitas Negeri Medan for facilitating the research process via Lembaga Penelitian Universitas Negeri Medan.

\section{REFERENCES}

1. Chu, W. L., Dang, N. L., Kok, Y. Y., Ivan Yap, K. S., Phang, S. M., \& Convey, P. (2018). Heavy Metal Pollution in Antarctica and its Potential ImpactsonAlgae.PolarScience, 20, 75-83. https://doi.org/10.1016/j.polar.2018. 10.004

2. Harikrishnan, N., Ravisankar, R., Chandrasekaran, A., Suresh Gandhi, M., Kanagasabapathy, K. V., Prasad, M. V. R., \& Satapathy, K. K. (2017). Assessment of Heavy Metal Contamination in Marine Sediments of East Coast of Tamil Nadu Affected by Different Pollution Sources. Marine Pollution Bulletin, 121 (1-2), 418-424.https://doi.org/10.1016/ j.marpolbul.2017.05.047

3. Mandich, M. (2018). Ranked Effects of Heavy Metals on Marine Bivalves in Laboratory Mesocosms: A Meta-Analysis. Marine Pollution Bulletin, 131 (Pt A), 773781. https://doi.org/10.1016/j.marpolbul. 2018.04.068

4. Riani, E., Cordova, M. R., \& Arifin, Z. (2018). Heavy Metal Pollution and its Relation to the Malformation of Green Mussels Cultured in Muara Kamal Waters, Jakarta Bay, Indonesia. Marine Pollution Bulletin, 133, 664-670. https://doi. org/10.1016/j.marpolbul.2018.06.029

5. Lestari, D. Y. (2010). Kajian Modifikasi dan Karakterisasi Zeolit Alam dari Berbagai Negara. In Prosiding Seminar Nasional Kimia dan Pendidikan Kimia.
6. Abou-Yousef, H., \& Hassan, E. B. (2014). A Novel Approach to Enhance the Activity of H-Form Zeolite Catalyst for Production of Hydroxymethylfurfural from Cellulose. Journal of Industrial and Engineering Chemistry, 20 (4), 1952-1957. https://doi. org/10.1016/j.jiec.2013.09.016

7. Ferreira, C., Araujo, A., Calvino-Casilda, V., Cutrufello, M. G., Rombi, E., Fonseca, A. M., \& Neves, I. C. (2018). Y ZeoliteSupported Niobium Pentoxide Catalysts for the Glycerol Acetalization Reaction. Microporous and Mesoporous Materials, 271, 243-251. https://doi.org/10.1016/j. micromeso.2018.06.010

8. Kim, J. Y., Heo, S., \& Choi, J. W. (2018). Effects of Phenolic Hydroxyl Functionality on Lignin Pyrolysis over Zeolite Catalyst. Fuel, 232, 81-89. https://doi.org/10.1016/j. fuel.2018.05.133

9. Yoshikawa, T., Umezawa, T., Nakasaka, Y., \& Masuda, T. (2018). Conversion of Alkylphenol to Phenol via Transalkylation Using Zeolite Catalysts. Catalysis Today. https://doi.org/10.1016/j.cattod.2018.08. 009

10. Cortés-Arriagada, D., \& Toro-Labbé, A. (2016). Aluminum and Iron Doped Graphene for Adsorption of Methylated Arsenic Pollutants. Applied Surface Science, 386, 84-95. https://doi.org/10.1016/J.APSUSC. 2016.05.154 
11. Jabbari, V., Veleta, J. M., Zarei-Chaleshtori, M., Gardea-Torresdey, J., \& Villagrán, D. (2016). Green Synthesis of Magnetic MOF@GO and MOF@CNT Hybrid Nanocomposites with High Adsorption Capacity towards Organic Pollutants. Chemical Engineering Journal, 304, 774783. https://doi.org/10.1016/J.CEJ.2016.06. 034

12. Lima, H. H. C., Maniezzo, R. S., Kupfer, V. L., Guilherme, M. R., Moises, M. P., Arroyo, P. A., \& Rinaldi, A. W. (2018). Hydrochars Based on Cigarette Butts as a Recycled Material for the Adsorption of Pollutants. Journal of Environmental Chemical Engineering, 6 (6), 7054-7061. https://doi. org/10.1016/J.JECE.2018.11.012

13. Liu, A., Wang, C.-Z., Chu, C., Chu, H.Y., Chen, X., Du, A.-F., ... \& Wang, C.-C. (2018). Adsorption Performance toward Organic Pollutants, Odour Control and Anti-Microbial Activities of One AgBased Coordination Polymer. Journal of Environmental Chemical Engineering, 6 (4), 4961-4969. https://doi.org/10.1016/J. JECE.2018.07.035

14. Martín, J., Orta, M. del M., MedinaCarrasco, S., Santos, J. L., Aparicio, I., \& Alonso, E. (2018). Removal of Priority and Emerging Pollutants from Aqueous Media by Adsorption onto Synthetic Organo-Funtionalized High-Charge Swelling Micas. Environmental Research, 164, 488-494. https://doi.org/10.1016/J. ENVRES.2018.03.037

15. Fedoročková, A., Hreus, M., Raschman, P., \& Sučik, G. (2012). Dissolution of Magnesium from Calcined Serpentinite in Hydrochloric Acid. Minerals Engineering, 32, 1-4. https://doi.org/10.1016/j.mineng. 2012.03.006
16. Sabolová, V., Brinek, A., \& Sládek, V. (2018). The Effect of Hydrochloric Acid on Microstructure of Porcine (Sus scrofa domesticus) Cortical Bone Tissue. Forensic Science International, 291, 260-271. https:// doi.org/10.1016/j.forsciint.2018.08.030

17. Zhu, K. R., Zhang, M. S., Hong, J. M., \& Yin, Z. (2005). Size Effect on Phase Transition Sequence of TiO2 Nanocrystal. Materials Science and Engineering: A, 403 (1-2), 87-93. https://doi.org/10.1016/j. msea.2005.04.029

18. Sau, T. K., \& Rogach, A. L. (2012). Complex-Shaped Metal Nanoparticles: Bottom-Up Syntheses and Applications. Germany: Wiley-VCH Verlag GmbH \& Co. https://doi.org/10.1002/9783527652570

19. Pauzan, M., Kato, T., Iwata, S., \& Suharyadi, E. (2013). Pengaruh Ukuran Butir dan Struktur Kristal terhadap Sifat Kemagnetan pada Nanopartikel Magnetit (Fe3O4). Prosiding Pertemuan Ilmiah XXVII HFI Jateng \& DIY, (ISSN : 08530823), 24-28.

20. Yokoyama, M., Ohta, E., Sato, T., Komaba, T., \& Sato, T. (1997). Size Dependent Magnetic Properties of Zinc Ferrite Fine Particles. Le Journal de Physique IV, 07(C1), C1-521-C1-522. https://doi. org/10.1051/jp4:19971212

21. Asmin, L. O., Mutmainnah, \& Suharyadi, E. (2015). Pengaruh Ukuran Partikel terhadap Struktural dan Sifat Kemagnetan Nanopartikel Zinc Ferrite (ZnFe204). Prosiding Simposium Fisika Nasional (SFN) XXVIII, 145-147. ISBN : 978-6028161-87-9 